\title{
Roma in the News: an examination of media and political discourse and what needs to change
}

\author{
Jo Richardson* \\ De Montfort University
}

\begin{abstract}
Roma, Gypsies and Travellers in Britain are marginalised in society and often the subject of negative discourse in media and political debate. This article examines why this matters through an example of a specific discourse incident in late 2013/ early 2014 , with the media reporting and political comment on the size and behaviour of the Roma population in the Page Hall area of Sheffield. Using a framework of antagonistic discourse as control startingfrom Foucault's work and bringing in Laclau and Mouffe, the article adapts concepts such as Galtung and Ruge's 'news values' in this particular episode and places it in the context of the wider Gypsy debate. It offers suggestions to think about taking forward a more positive debate on Roma, Gypsy and Traveller communities in Britain, which could try to counterbalance the hysteria that often takes place in the press.
\end{abstract}

Keywords: Roma, Gypsies, Travellers, media, political, discourse, conflict.

\section{Introduction}

There is a problem in the way that Roma, Gypsies and Travellers are portrayed in media and political debate. The popular media representation of these already misunderstood groups can further feed fear and paranoia and exacerbate community conflict. Where the media and political discourse combine to utilise 'dog-whistle' politics in order to get a reaction from a particular segment of the population, the impact can be amplified and tensions heightened further. Why does it matter what the papers say? It matters because anti-Gypsy discourse is hegemonic and can constrain groups' freedom to practice individual cultures through heightening their 'otherness' and therefore subjecting them to increased social surveillance and control.

Torfing (1999) sums this up nicely in terms of hegemonic force of the social construction (and reconstruction) of identities:

Hegemonic articulation ultimately involves some element of force and repression. It involves the negation of identity... [which] ... tends to give rise to social antagonism. The hegemonic force, which is responsible for the negation of 
individual or collective identity, will tend to construct the excluded identity as one of a series of threatening obstacles to the full realization of chosen meanings and options. (pg. 120)

Through a content analysis approach, this articlewill examine a particular, recent example of press and political discourse on the Roma community in Sheffield, and offer a framework which shows the demonisation in the social construction of the public imagining of 'Roma'. I will reflect on previous research (Richardson, 2006) which looked at the media discourse surrounding Gypsies and Travellers ten years ago and draw parallels in the themes and news values used then and now.

The approach taken in the article focuses on analysis of newspaper stories which searched for particular themes that typify this hegemonic anti-Gypsy debate and that might explain the mostly negative, circular discourse. To do this, I use a framework of 'news values' as developed by Galtung and Ruge (1965) and at points during the analysis of the news, I attempt to link to specific values. Galtung and Ruge (1965) observed 12 factors that helped events become news as shown in figure one below. Four of these factors are examined in a little more detail in the next section, but the overall framework of news selection is important to the arguments in this article.

Figure 1: Conditions that allow events to become news (Galtung \& Ruge, 1965, 70-71)

$$
\begin{aligned}
& \text { F1: frequency } \\
& \text { F2: threshold } \\
& \text { F2(i): absolute intensity } \\
& \text { F.2(ii): intensity increase } \\
& \text { F3: unambiguity } \\
& \text { F4: meaningfulness } \\
& \text { F4(i): cultural proximity } \\
& \text { F4.(ii): relevance }
\end{aligned}
$$

F5: consonance

F5(i): predictability

F5 (ii): demand

F6: unexpectedness

F6(i): unpredictability

F6(ii): scarcity

F7: continuity

F8: composition

F9: reference to elite nations

F10: reference to elite people

F11: reference to persons

F12: reference to something negative

More important though, is the process of selection, distortion and reconstruction of Roma identity within the chain of media and political discourse that frames arguments. I suggest that certain 'whistle words' are used that link to some of Galtung and Ruge's news values which prompt further negative social construction of Roma, Gypsy and Travellers, but that these should also be used as 'bounce points' where community 
members and advocates should interrupt this hegemonic practice with a reassertion of a more realistic and recognisable Roma identity.

This article starts with an explanation of the Roma news event, by analysing a series of news articles against news values, and by identifying 'whistle words'. There is then a discussion on how, through a discussion of Galtung and Ruge's news values, and through an adaptation of their understanding of selection and distortion of news, negative discourse by the press and politicians is amplified into a hegemonic cacophony which can control the 'other'; the work of Foucault (1980) and Laclau and Mouffe (2001) helps to explain this further. A brief debate on the 'viral' nature and negative impact of some social media discussion is then followed by conclusions and recommendations.

\section{The Roma in Page Hall, Sheffield, 'News Event'}

I examined news reports over a six-month period from September 2013 to February 2014. Using the Lexis Nexis news database, all UK newspapers over this period were searched on the terms 'Roma' and 'Sheffield' to be found in the body of the article. Over 300 articles were found, but after discounting irrelevant articles (for example about football) there were 89 articles remaining. The first was from the Sheffield Telegraph on $7^{\text {th }}$ September2013 and it reported a public meeting held at the Pakistan Advice Centre in Page Hall, where over 100 people attended and a number of issues were discussed. The article said: "Problems raised ranged from fly-tipping and litter to intimidating groups of up to 30 people on the street, loud music late at night - and child prostitution and sex grooming of underage girls." It was also reported in the article that a local voluntary worker from Page Hall "warned police and councillors at the meeting that action needs to be taken urgently - or people's anger would boil over". In response Police Inspector Leake was quoted at length where he talked about the use of legal remedies such as a Dispersal Order and asked the community to come forward if they were aware that criminal behaviour was taking place; but he also said: "From a policing perspective, we are telling the community that we want tolerance. We want different parts of the community to respect each other and resolve the issues."

By contrast the second of the 89 articles was from the Mail on Sunday on $20^{\text {th }}$ October - its headline was Ramshackle Roma Camp Where Greek Maddie Was Discovered (Murphy, 2013). The only reason that 'Sheffield' was in the article was because a comparison was made with the Ben Needham child abduction case from 1991, and Ben was from Sheffield. The child in the Greek abduction case that the Mail was reporting on was actually called Maria, but the use of 'Greek Maddie' is a classic example of the use of news values 11 and 12 (reference to persons and negative reference) from Galtung and Ruge (1965); as well as values 1 and 7 (frequency and continuity) allowing them to keep the Maddie story alive and linking it to a negative story about Roma. Galtung and Ruge's framework of news values will be discussed further in this paper in the section on 'amplification of bad news.' Eight national newspaper stories, out of the total 89 articles, were focused on the Greek Roma kidnapping story.

On October 31 2013 The Telegraph's Hayley Dixon reported under the headline 'UK's Roma population much higher than previously thought': "New research estimates that there are 200,000 Roma living in the UK, despite government claims two years ago that "relatively few" had settled in the country". The Scottish Express headlined its discussion of the research report: 'Roma surge will add to our 200,000' (Dawar, 2013) and said: "An estimated 200,000 Roma gypsies [sic] are already living in Britain - one of the biggest populations in western Europe, research claims. And frontline officers 
fear the figure will rocket once visa restrictions are lifted at the end of the year according to the University of Salford study." Six national newspaper articles had headlines on the research estimating the size of the UK Roma population by Brown et al (2013) with headlines showing varying degrees of alarm; for example Perkins (2013) for the Daily Star: 'ROMA ARMY, 200,000 are here with more on the way.' The research was debated on the Channel 4 news and was also represented on TV (but that is not included in this analysis).

There was then a collision between the news discourse and political discourse in a series of articles quoting Sheffield MP David Blunkett. For example on November $11^{\text {th }}$ 2013, The Telegraph's political correspondent (Holehouse, 2013) wrote: "Roma migrants could cause riots in cities, warns Blunkett; British cities could face race riots as an influx of Roma migrants creates "frictions" with local people, David Blunkett warns." The article quotes an interview that Blunkett gave BBC Radio:

The cultural gulf between the Roma and the settled community is 50 per cent greater than that between white Britons and Pakistani immigrants who came to Britain a generation ago, Mr Blunkett told BBC Radio. "The Roma youngsters have come from a background even more different culturally, because they were living in the edge of woods, not going to school, not used to the norms of everyday life. We've got to change that," he said. (Holehouse, 2013)

In a blog for the Telegraph online, Gallagher (2013) talked about Blunkett's comments as being justifiable and challenged the 'left-wing human rights industry' representation of Roma. He said, of Blunkett's riot warnings: "The state's authority is relatively brittle and in places like Sheffield, there is plenty of seething discontent over having turned into post-industrial reservations. So I believe that Mr Blunkett's fears are not inflammatory ones." Riley-Smith (2013) also supported Blunkett in the story headed: “Nigel Farage: 'Blunkett right to warn Roma migrants could trigger riots'; Ukip leader says former home secretary "should be admired for speaking out about the issue."

The Daily Star did not disappoint with its headline on page 4 on $13^{\text {th }}$ November: 'I Predict a Riot over UK Roma Invasion!' (Nicks, 2013).Over the three days from November $11^{\text {th }}$ to November 13 th there were 12 articles discussing Blunkett's riot warnings identified in the Lexis Nexis search. Then there was the story of Roma migrants in Page Hall offering to sell their baby. This almost fairytale arc to the media discourse on the Roma in Sheffield is not new; 'stealing babies' (or in this case selling them) is a well pedalled aspect of the 'othering' of Roma, Gypsies and Travellers (Richardson, 2006). There were five articles, in the middle of November, that reported on the baby story.

From November $13^{\text {th }}$ the headlines had turned to the impact of Blunkett's remarks on the local community in Page Hall, for example with increased local community surveillance as reported in The Daily Mail (Brooke, 2013): 'After the Blunkett Warning, Residents on Patrol in His City.' A further four articles talked about the impact of Blunkett's warning and then a number of articles followed, reflecting the political arguments between Clegg, Cameron and others on whether Blunkett should have said what he did.

The Scottish Express on November 16th ran an 'Exclusive' on 'Roma migrants boast of raking in huge benefits' (Jeeves, 2013) and Walker (2013) for The Daily Star reported Roma Girls in British 'Sex shop windows'; 'Hookers, 12, bonk for £2'. Thus bringing together news values with real 'grip' - underage sex and benefits deceit - into the hegemonic anti-Gypsy discourse. These more lurid and 'outrage' themes are designed to speak more strongly to certain parts of society. The dog-whistle key themes 
of selling/stealing babies, under-age prostitution, and claiming benefits are designed to catch the attention of Conservative voters, and it suits the right-leaning political elite that this discourse is perpetuated in the newspapers and in Parliament. Notable in their rarity were the articles that attempted to redress the balance in the way Roma were represented. Townsend (2013) for The Observer on $17^{\text {th }}$ November found “... a huge gap between the perception and reality of Roma life."

By $21^{\text {st }}$ November, the newspaper stories had turned to critical debate of 'tax-payer funded' leaflets telling Roma 'Don't spit or have sex in the street or your neighbours will think you're dirty' (Webb, 2013). There were four national newspaper articles taking a critical view of a Sheffield City Council leaflet to help Roma settle into local communities.

The stories in the Roma/Sheffield news event in late 2013/ early 2014 started with the reporting of community disquiet in Page Hall, Sheffield, about the number and behaviour of Roma in the community. In late October this was followed by news reporting of research (Brown et al., 2013, see Brown et al, this issue) estimating the size of the Roma population in the UK; providing an opportunity for the media panic about a number of issues including the scale of immigration from Europe and 'other' cultural behaviour of Roma. The story arc then brought into play political voices from Blunkett and colleagues, but also took in fantasmatic themes such as under-age prostitution and selling babies, in addition to themes of anti-social behaviour and dumping rubbish. These 'whistle words' chime with previous research (Richardson, 2006) that found 'mess' and 'cost' were two key themes that gripped in the media and political debate on Roma and accession from new EU countries ten years ago.

The words most regularly used, through a content analysis in Nvivo, were unsurprisingly Roma, Sheffield and Blunkett. Further 'whistle words' used in the news event were:

- Migrants (186)/ Immigrants (135)

- Benefits (81)

- Rioting (80)

- Work (78)

- Behaviour (77)

- Tensions (71)

- Influx (48)

- Rubbish (38)

- Intimidating (33)

- Sex (24)

- Fear (23)

These are just a selection of key whistle words identified in the analysis of the articles that represent key moments in the story arc. The figure below represents the usage of different words in the sample of 89 articles analysed. 
Figure 2: Word usage in Roma news event 2013/14

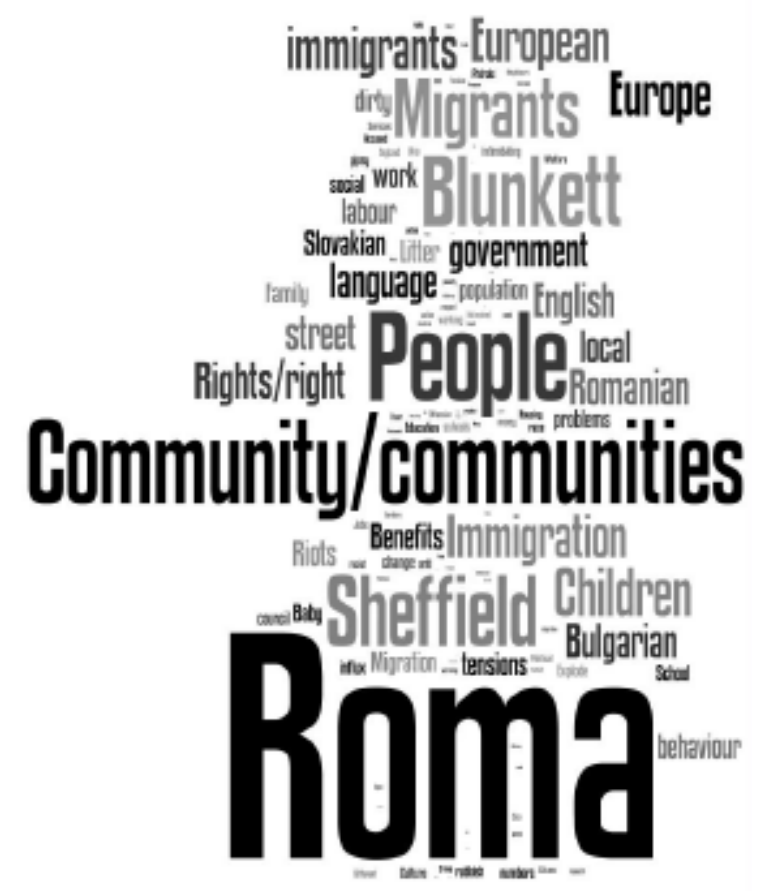

There were additional national newspaper stories reporting on Roma that fell outside of this content analysis. Because the article had wanted to look more closely at the Page Hall, Sheffield news event I had used the search terms 'Roma' and 'Sheffield' - therefore news reports just talking about Roma and not mentioning Sheffield anywhere did not show in the 89 articles analysed. One news report outside the 89 sample (Reid, 2013) for the Mail Online gave a very detailed account of a Roma family living in Paris and it talked about the strain of immigration on health services in the UK but also provided a nuanced account of personal stories of Roma affected by camp clearances across Europe with examples in France and Germany. The report went beyond the 'grip' of negative news values and demonstrates the complexity of news representation of the issue - it goes beyond the binary assumption Guardian good/ Daily Mail - bad and shows that just as there are inconsistencies and arguments amongst community members and scholars in this Roma debate, so there are differences of opinion amongst journalists - even within the right-leaning tabloid press. Considered news articles like these glimmer and gleam in their rarity, and those agitating for change should use these examples to 'bounce' journalists and politicians into a more positive and nuanced debate.

The political and media discourse 'event' that occurred in November 2013 was intense, disturbing and had a negative impact on the local community in Sheffield - not just for the Roma, but it heightened tensions for the whole community. Was it a new phenomenon? Certainly not: ten years ago in discussing the accession to the EU of the A8 countries and the 'influx' of Roma, The Daily Express, for example, used a war-like image to show the Roma 'invasion' and the media debate at that time used many of the 'whistle words' seen in the recent Roma news event in 2013/14. 


\section{The amplification of bad news about Roma; discourse in the news: a theoretical framework for othering}

There is an inter-relationship between the factors and also sub-factors to be considered by Galtung and Ruge (1965) in their news value framework (outlined in Figure 1 earlier in the article). Galtung and Ruge were talking about the structure of foreign news in their original work and so some of the factors in Figure 2 may not be so relevant to domestic media reporting of Roma, Gypsy and Traveller issues. However, some factors are very relevant; two in particular strike a chord:

- 'Reference to persons', or 'personalization' (promoting feelings of identification, empathy and disapproval). What do Roma, Gypsies and Travellers 'stand for'? Media analysis research on Gypsies and Travellers (Richardson, 2006) showed themedia reflection of them as 'standing for' a cost to the taxpayer, causing a mess and being 'other' to the settled community.

- 'Meaningfulness' (including 'cultural proximity' and 'relevance' this relates to consensus and conforming to norms). The ramifications of stereotyping in the press are clear, when an event is reported in the news it reinforces the stereotype; and the fact that a stereotype is part of the event makes it more newsworthy.

Less convincing, in this context, are conditions like F3 'Unambiguity' in the Galtung and Ruge framework considering what we know about media reporting on Roma. A related point on the importance of 'empty signifiers' in the hegemonic practice of discursive control, will be discussed shortly. Ambiguity and the opportunities to refix identities through shifting discursive frames and 'whistle words' is a prominent and recurring aspect of the debate on Roma in media and political discourse.

Galtung and Ruge propose a binary approach to either presence or absence of a particular factor - so if all factors are present then the score is 12 and if none are, then 0 . The higher the score the more likely the event is to make the news. This is an interesting approach and one which can be adapted for specific types of news events. However, the key message I take away from Galtung and Ruge's work is their idea on selection and distortion. At each stage of a chain of communication there is scope for the receiver to select a message and then distort it. This can create an ever decreasing circle of reality as the distortion becomes the new image, which becomes the new perception, which is distorted, and so on. This is how social identities are constructed and re-constructed. An adaptation of this selection and distortion cycle of news is shown in Figure 3. 


\section{Figure 3: Amplifying and reinforcing hegemonic stereotypes of Roma}

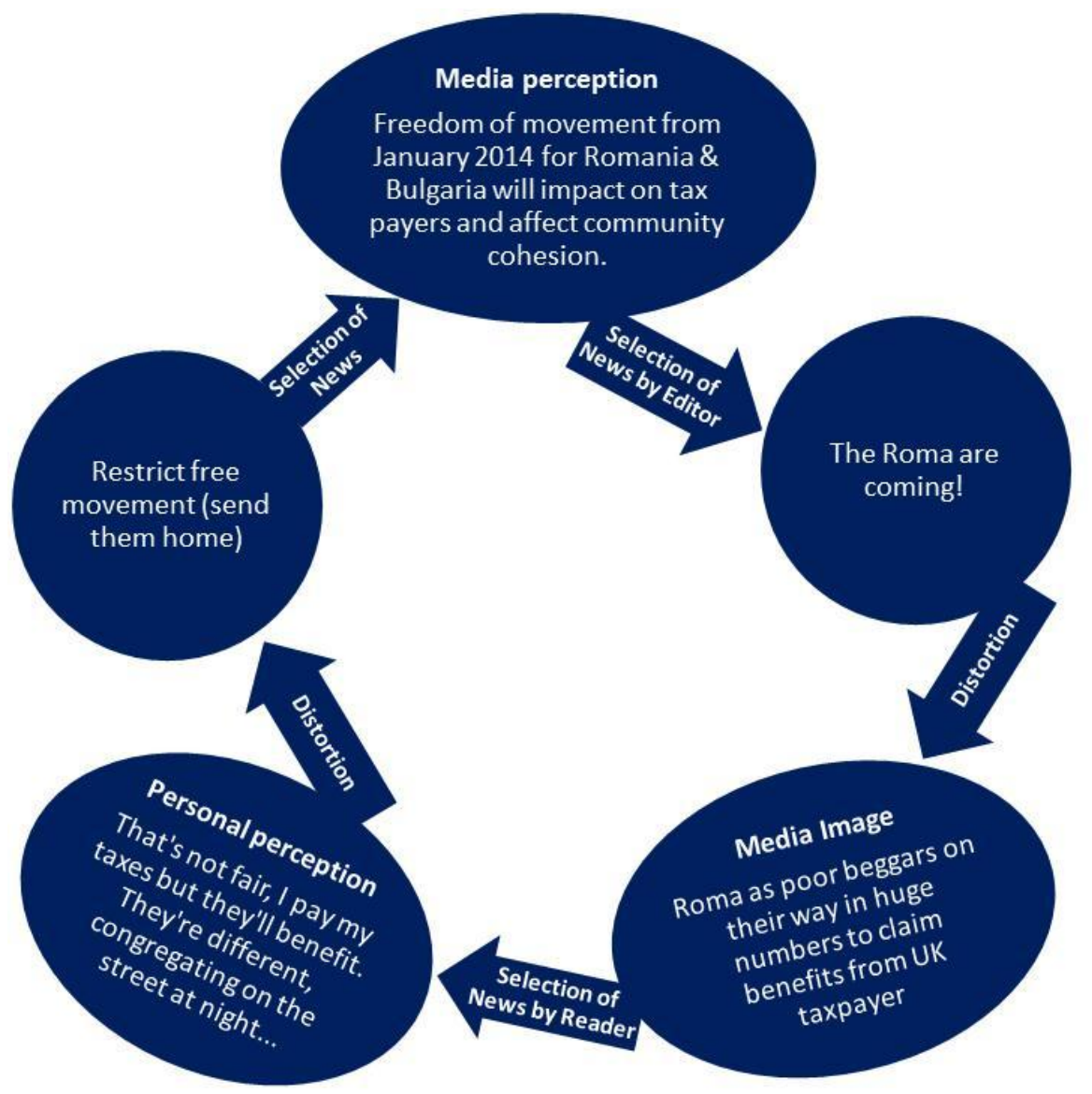

Fowler (1991) talks about the importance of 'stereotype' as part of a cognitive process allowing us to sort through a mass of information, categorising and sorting to make sense of it. These moments of understanding through sorting happen at moments of selection and 'distortion' as discussed by Galtung and Ruge at many different points, by the author, again by the editor, then by the reader, and again by the person the reader talks to about the story, and so on. Stereotyping is an ongoing reinforcing process.

The linguistic construction of social reality is a powerful tool in creating categories and sorting them into 'conflictual opposites' (Fowler, 1991: 6). With the example of Roma, Gypsies and Travellers, the news constructs them and the settled community as conflictual opposites. After a while this construction of reality sees Roma as embodying the enemy of the 'normal' settled community.

The media is not merely a reporting mechanism that reflects events and feelings, it helps instead to create and shape events and feelings. Dean (2011) demonstrates that the media does not just report on government, but instead shapes policy and political decisions. It also shapes debates and opinions in the community. The negative images used to portray Roma, Gypsies and Travellers in some sections of the media, serve as a tool to highlight their 'otherness' and their so-called deviancy from societal norms. Labelling Roma, Gypsies and Travellers as 'other' is actually making them 'other'; their identity is reconstructed as different in the public imagination and this can result is 
physical and social exclusion (Richardson, 2006). The role of Roma, Gypsies and Travellers as folk devils is played out in government policy decisions and reinforced by the media, feeding back again into government reacting to media representation with the introduction of populist policies: as was seen in the Express 'campaign' against East European Roma, January 2004 (see further Richardson and O’Neill, 2012).

Foucault (1980) saw the concept of discourse and power as fluid, but thought about bases and targets of power, and saw that there was not necessarily a central originator or target of power, as such. Hesaw instead a plurality of power and noted the flow and resistance in power: "Power is employed and exercised through a net-like organisation... In other words, individuals are the vehicles of power, not its point of application." (Foucault, 1980: 98)

This network of power means that it takes a network of agitators to create change in the discourse and a range of people from communities, academic institutions, journalists and politicians need to engage positively as vehicles in that network to help recreate a more positive and nuanced debate. Taking Foucault's ideas into a further dimension, Laclau and Mouffe (2001: 135) discuss 'hegemonic articulations' which they suggest are based on two core aspects: (1) articulatory momentsand (2) confrontational antagonistic practices. It is not enough for just articulation, or antagonism for hegemony to take place, but the articulation must occur within antagonistic practices. The antagonistic forces are fluid and not fixed; differences can be constructed and reconstructed. If we think about the social construction of Roma in the social space, we can see the construction of identity which creates antagonistic communities, and yet the identity is not fixed but constantly changing. The story arc in the Roma news event 2013/14 showed the changing discourse codes used to keep identities from fixing for long enough for them to be rebutted.

Laclau and Mouffe (2001) discuss the notion of 'empty' or 'floating' signifiers in discourse and the lack of fixity in social identities. They suggest that:

The practice of articulation, therefore, consists in the construction of the nodal points which partially fix meaning; and the partial character of this fixation proceeds from the openness of the social, a result, in its turn, of the constant overflowing of every discourse by the infinitude of the field of discursivity. (pg. 113)

Signifiers (and any solid meaning of things) can only ever be partially fixed because the field of discursivity (the context for the debate) is constantly changing and overwhelming any momentary understanding of what a particular node (thing, person, group) is. So, a newspaper journalist may claim to know exactly who the Roma are, but their attempt to fix meaning is overwhelmed by new information and by wider reactions to their attempt to fix meaning. This changing discourse which overflows partially fixed meanings of social identity can be seen to occur not just in the external debate which socially constructs and re-constructs identities (e.g. the debate about the Roma in Page Hall by public, press and politicians), but also the internal debate within and between Roma, Gypsy and Traveller groups themselves.

Roma, Gypsies and Travellers are 'ghettoised' either in social or physical space. In the social, they are re-imagined and re-constructed as 'other' in some way. In the physical space, Gypsies and Travellers can be excluded from the community through the location of their site (authorised or not) which is more often than not on the periphery of a community or on reclaimed disused brownfield spaces. Roma across Europe find themselves literally segregated into ghettos; Powell (2013) discusses the use of the term 'ghetto' and utilises a framework developed by Wacquant to better understand BME groups and their social relations with 'host' populations. In relation to the media event of the Roma settling in Sheffield, Page Hall is clearly not a Roma 
ghetto and yet there are elements of explanations by Powell that resonate with the exclusion and stigmatisation of Roma either in the physical space or the social imagination. This is discussed further by Vincze and Rat (2013):

The social and cultural formation of "Gypsy ghettos" mirrors a largerphenomenon happening across borders, that is the trend of territorialisation ofsocial exclusion coupled with territorial stigmatization (Wacquant, 2007). Theseare processes by which precarious social categories (created by economicmechanisms and stigmatized by concepts that blame the poor for being poor) areplaced into marginal (for the most of the time polluted) locative spaces. (page 7)

\section{Viral news: contagious hegemonic discourse}

A failure to secure more responsible reporting on Roma, Gypsies and Travellers has meant that negative and inflammatory reporting can continue unchecked. In addition to this, the potential for social media platforms to make messages viral means that anti-Gypsyism has flared into open intimidation. The media is now more pervasive than ever thanks to the improvement of information and communications technology. Social media, for example Twitter and Facebook, has seen positive campaigns (such as in support of the Green Revolution in Iran in 2010) and this sort of online collective action - 'clicktivity' - can be a democratic force for positive change, it can also have negative connotations. There are examples of racist hate campaigns going viral. For example, events in June 2009 in Belfast made their way quickly to national and international headlines (McDonald,2009) and they underlined a latent racism against Roma, Gypsies and Travellers and the physical threats and hate campaigns that, in this instance, resulted in the 'Roma going back' and leaving Belfast under police guard.

This social media extends to social conversations online in the comments section at the end of news articles, and it is where anti-Gyspy discourse is prevalent. Individual comments can turn into an online social conversation that constructs and reconstructs the original news story even further and the image can become even more negative. For example, comments following news article by De Peyer, 2013, (accessed online 24th February, 2014):

\section{Rich'n104 days ago}

People changing their culture to live in the UK? that would be a first. Here's what will really happen: the Roma will come over, take all the benefits they can grab and supplement the benefits by begging, crime and prostitution. And the UK taxpayers will continue to bend over for the rest of the world.

\section{anarchist666104 days ago}

This is going to be absolute hell. We've got six weeks left to pull the UK out of Europe before we are bankrupted by these third world savages. Rich'n is spot on: the only thing I can add is pick-pocketing and cashpoint fraud to their list of unpleasant features

Mark, 104 days ago

C4 News did a report on this a week or so back from Sheffield. It was evident after about two minutes you don't want them to be living close to you.

There is a space for those who agitate for more positive representation to interrupt these social comments and to provide facts and positive stories where appropriate, so as to reshape the hegemonic discourse of negative social online commentary. What 
can sometimes happen though if a positive comment, or a comment challenging negative and discriminatory discourse is posted, the editor of the page closes the comments section down before the debate can be turned around into something more nuanced and persuasive.

In the process of agitating for more positive representation, there are issues raised - not just in media and political discourse - such as increased litter in an area, antisocial behaviour and overcrowding. These issues still need to be physically addressed through legal remedies, or provision of public services, or information. Not all issues are about changing perception and debate. However, even when the local authority in Sheffield did try and provide information to the new Roma community on how best to settle in, the media chose to report that as a waste of tax-payers' money, rather than getting behind the attempt to improve community cohesion in the area.

\section{Conclusion: A New Framework}

Moral outrage and legal action certainly have a place in the resistance to the hegemony of antagonistic news practice in representing the Roma in media and political debate. The action brought by the Irish Traveller Movement in Britain (ITMB) in 2012 against Channel 4 for its advertising campaign for the television series Big Fat Gypsy Weddings showed that the existing legal mechanisms do work - on very seldom occasions. However, one can see from the similarities in the way Roma were depicted in the Page Hall, Sheffield news event at the end of 2013 with the way the A8 accession to EU possible 'Roma invasion' was articulated in the press in 2003 and 2004 (Richardson, 2006 and Richardson and Ryder, 2012),that the small steps that have been made have not been sufficient to break the negative discourse cycle.

Nevertheless, the positive steps that have been taken so far must be acknowledged. This article has discussed the hegemonic anti-Gypsy political and media debate particularly around the Page Hall media event. However, there are leading political voices, particularly in the House of Lords who do make very definite steps to disrupt the negative discourse. On $2^{\text {nd }}$ April 2014 there was a House of Lords Debate on the International Roma Day, initiated by Baroness Janet Whitaker, a longstanding advocate for Roma rights. The debate included speeches from a number of Labour Lords and Conservative Peer Baroness Warsi who, amongst other points, attempted to reply to a question on when the government would comply with EU requirements to draw up a Roma Inclusion Strategy. This more positive, nuanced political debate does not contain the 'whistle words' or meet some of the Galtung and Ruge news values, and thus is not in the newspapers the next day changing opinion. However, it is a good example of using the 'bounce point' of International Roma Day to create a balanced political debate.

What is needed is a better understanding of the 'grip' points specifically in the Roma, Gypsy and Traveller debate. Which characteristics, labels and 'whistle words' seem to grab the public imagination in the selection, distortion and re-articulation of Roma, Gypsy and Traveller as 'other' and indeed not welcome? Earlier in this paper, I set out a series of key words found in the content analysis of the Page Hall, Sheffield Roma news event of late 2013. Just as these key words may be seen as a 'grip' point in terms of news value and social reconstruction of image; so they must also be used as points to 'bounce' real Roma, Gypsy and Traveller lives: reflecting the positive to balance the negative. It is only by re-shaping popular perception and image that the hegemony of negative news can be resisted.

This proposal to 'bounce' positive and real images to resist the distorted social constructions of Roma in media and political discourse is a challenge, as there are 
communities within communities who cannot agree a consistent message because there are no single identities. There are arguments within Roma, Gypsy and Traveller communities about identities: who is 'real' and who represents issues? Equally, there are robust arguments in the academic community on the issues too for example a challenging debate on the methodology and public representation of the estimated size of the Roma population in the UK by Brown et al (2013) is still ongoing.

If there is no cohesion in the most well-meaning communities of Roma, Gypsy and Traveller groups and scholars researching in the area, then what hope is there of a concerted effort to resist the hegemony of anti-Gypsy discourse? It suits those in power well (government and owners of news organisations) if we are all so busy arguing that the potential for resistance is diluted. Of course arguments of identity should remain, and challenges between scholars are ingrained in robust academic practice. However, I suggest that at critical moments of antagonistic discourse there should be a quick and cohesive response from agencies that represent the interests of Roma, Gypsies and Travellers with the support and evidence from those who research in the field. There are successes in resistance such as by ITMB in response to Channel 4, but there is scope for widening out such successes across a range of news and political events affecting a number of Roma, Gypsy and Traveller groups.

There should also be a robust challenge by academics and representative bodies to the government's lack of engagement with the European Union strategies on Roma inclusion. Organisations like the National Federation of Gypsy Liaison Groups are leading the way on this with their work on a shadow strategy to make up for the government's lack of leadership and ambition to improve equality and inclusion in this area.

A number of 'bounce' points present themselves to agitators for change in the way Roma, Gypsies and Travellers are represented in the press. As Foucault (1980) noted there are multiple targets and bases of power that can be challenged. The "whistle words' identified in the content analysis of the Roma news event in 2013/14 can be understood better in a framework such as Galtung and Ruge's (1965) conditions but certain factors need to be critically assessed as we know that ambiguity through empty signifiers in discourse (Laclau and Mouffe, 2001) seem to be particularly useful in the news debate, allowing hegemonic re-articulation of the 'otherness' of Roma. There is space for academics, community members, responsible journalists and politicians to re-imagine, and contribute to, a new more nuanced public debate.

* Correspondence Address: Jo Richardson, De Montfort University, Department of Politics and Public Policy, The Gateway, Leicester, LE1 9BH. Email: jrichardson@dmu.ac.uk 
p. 63. Roma in the News: an examination of media and political discourse and what needs to change

\section{References}

Brooke, C. (2013) After the Blunkett Warning, Residents on Patrol in His City, Daily Mail, 13 November, online via Lexis Nexis (accessed 17 February 2014)

Brown, P., Scullion, L. and Martin, P. (2013) Migrant Roma in the United Kingdom: population size and experiences of local authorities and partners. Salford: University of Salford online.

Dawar, A. (2013) 'Roma surge will add to our 200,000', Scottish Express, 31 October, online via Lexis Nexis (accessed 17 February 2014).

Dean, M. (2011) Democracy under attack: How the media distorts policy and politics. Bristol: Policy Press.

DePeyer, R. (2013) 'Tensions with Roma migrants could lead to rioting, David Blunkett warns', London Evening Standard, 12 November, online via Lexis Nexis (accessed 17 February 2014)

Dixon, H. (2013) 'UK's Roma population much higher than previously thought', The Telegraph, 31 October, online via Lexis Nexis (accessed 17 February 2014)

Foucault, M. (1980) Power/Knowledge,(ed). C Gordon. Harlow: Pearson Education Ltd.

Fowler, R. (1991) Language in the News, Discourse and Ideology in the Press. London: Routledge.

Gallagher, T. (2013) 'What the Left-wing human rights industry won't tell you about the Roma', The Telegraph, 12 November, online via Lexis Nexis (accessed 17 February 2014)

Galtung, J. and Ruge, M. (1965) The Structure of Foreign News. Journal of Peace Research, 2, 1, 64-91.

Holehouse, M. (2013) 'Roma migrants could cause riots in cities, warns Blunkett', The Telegraph, 11 November, online via Lexis Nexis (accessed 17 February 2014)

House of Lords Debate (2014) 2 April 2014, Column 976 - 988.

Jeeves, P. (2013) 'Roma migrants boast of raking in huge benefits', Scottish Express, 16 November, online via Lexis Nexis (accessed 17 February 2014)

Laclau, E. and Mouffe, C. (2001) Hegemony and Socialist Strategy, towards a radical democratic politics ( $\left.2^{\text {nd }} e d\right)$. London: Verso.

McDonald, H. (2009) 'Romanian gypsies beware beware. Loyalist C18 are coming to beat you like a baiting bear', The Observer, p.22.

Murphy, S (2013) 'Ramshackle Roma Camp Where Greek Maddie Was Discovered', Mail on Sunday, 20 October, online via Lexis Nexis (accessed 17 February 2014).

Nicks, G. (2013) 'I Predict a Riot over UK Roma Invasion!' Daily Star, 13 November, online via Lexis Nexis (accessed 17 February 2014).

Perkins, H. (2013) 'ROMA ARMY; 200,000 are here with more on way', Daily Star, 1 November, online via Lexis Nexis (accessed 17 February 2014).

Powell, R. (2013) Loïc Wacquant's 'Ghetto' and Ethnic Minority Segregation in the UK: The Neglected Case of Gypsy-Travellers. International Journal of Urban and Regional Research, 37, 1, 115-134.

Reid, S (2013) 'The Roma and the march of the ugly Right: A deeply troubling dispatch from Paris and Berlin that EVERY British politician must read', Mail Online, 18 October(accessed 18 December 2013).

Richardson, J. and O'Neill, R. (2012) 'Stamp on the camps: the social construction of Gypsies and Travellers in media and political debate', In: Richardson, J. and Ryder, A. (Eds) (2012) Gypsies and Travellers: Empowerment and Inclusion in British Society. Bristol: Policy Press.

Richardson, J. and Ryder, A. (Eds) (2012) Gypsies and Travellers: Empowerment and Inclusion in British Society. Bristol: Policy Press.

Richardson, J. (2006) The Gypsy Debate: can discourse control? Exeter: Imprint Academic. 
Riley-Smith, B. (2013) 'Nigel Farage: 'Blunkett right to warn Roma migrants could trigger riots', The Telegraph, 12 November, online via Lexis Nexis (accessed 17 February 2014).

Sheffield Telegraph (2013) 'Sheffield police vow to tackle migrant tensions', Sheffield Telegraph, 7 September, online via Lexis Nexis (accessed 17 February 2014).

Torfing, J. (1999) New Theories of Discourse: Laclau, MouffeandŽižek. Oxford: Blackwell Publishers Ltd.

Townsend, M. (2013) 'Special report: The real story of Britain's Roma: excluded, ignored and neglected', The Observer, online via Lexis Nexis (accessed 17 February 2014)

Vincze, E. and Rat, C. (2013) Spatialization and Racialization of Social Exclusion.The Social and cultural formation of 'Gypsy Ghettos' in Romania in a European Context. StudiaUbbSociologia, LVIII, 2, 5-21.

Walker, M. (2013) 'Roma Girls in British Sex Shop Windows', Daily Star, 16 November, online via Lexis Nexis (accessed 17 February 2014).

Webb, S. (2013) 'Don't spit or have sex in the street or your neighbours will think you're dirty: Taxpayer-funded leaflet produced to teach migrants about anti-social behaviour', Mail Online, 21 November, online via Lexis Nexis (accessed 17 February 2014). 